\title{
ZAMBIAN CHILDREN'S IMAGINAL CARING: On Fantasy, Play, and Anticipation in an Epidemic
}

\author{
JEAN HUNLETH \\ Washington University in St. Louis \\ (iD) https: / / orcid.org/0000-0003-4516-4407
}

In August of 2007, eight-year-old Gift Munkanta rose up into the sky and took flight. ${ }^{1}$ He flew away from the farm in rural Zambia where he lived with his grandparents, past fields that gave way to buildings as Lusaka, the capital city, came into view. Gift flew over the buildings and descended into the University Teaching Hospital where his one-year-old sister was a patient, seriously ill with tuberculosis (TB).

Gift pointed to the illustration he had made of his sister in a hospital bed and told me, "I put her on my balloon." Interrupting his story, he ran into a bedroom to retrieve a deflated red balloon as proof that he really possessed such a thing.

Gift then continued his tale. He and his sister used the balloon to float away from the hospital and toward the family house in George, a residential area of Lusaka, where we sat. When the siblings reached the house, the balloon became a parachute, he explained, and they descended.

Once in the house, Gift watched over his sister, which was not easy, he showed, as he pointed to the page: "This is a snake that wanted to kill her. I used my bow and arrow and killed it." He again ran into a bedroom. This time he returned with a bow that he had fashioned out of a small branch and some string. 


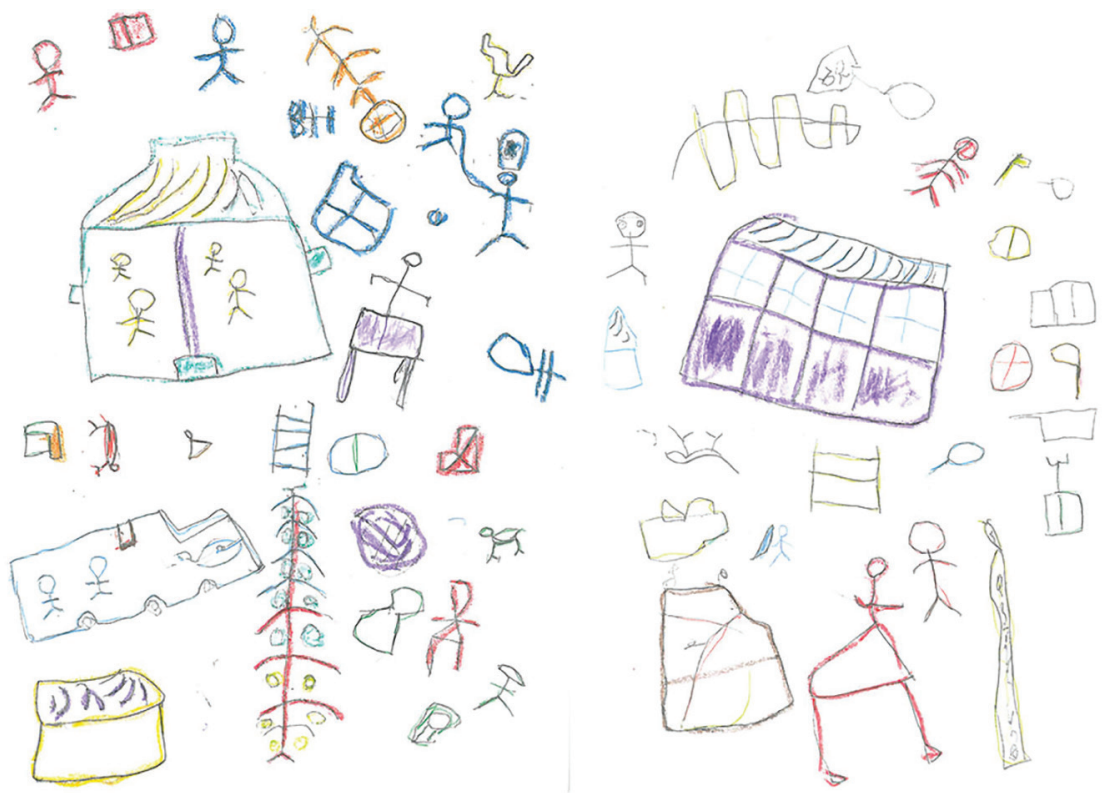

Figure 1. Gift's drawing and the words he used to describe it tell the story of flying to the University Teaching Hospital where Gift's baby sister had been admitted, taking his sister home using a balloon, and caring for her through her illness and into their adulthoods. Drawing by Gift Munkanta.

Looking back at his drawing, he pointed to a bus. It was now the future, and he was a driver. With all the money he made, he explained, he had built a large house in a high-income area of Lusaka. He pointed to stairs he had drawn on the page, thus confirming his financial success, for only wealthy people have houses with two stories. His baby sister, who was also now grown, lived in the crayon-drawn house with him, and they looked after one another.

$$
* * *
$$

We have a mantra in childhood studies: children have agency. We repeat this mantra because children's agency has been ignored for so long in ethnographic research. In my own research, I have shown that children play active roles in caring. Children do things within times and spaces characterized by illness: they nurture bodies and minds; they sustain relationships, upholding households and families under duress; they assist states struggling with gutted health-care systems. Their caregiving might even sustain global health policies and programs in ways yet unrecognized. But, as researchers have argued, there is a dark side to our mantra. An overemphasis on children's agency — understood as the active roles children take in the world - invites us to overstate children's power, understate their vulner- 
ability, and insufficiently problematize the constraints placed on children (Bluebond-Langner and Korbin 2007; Allerton 2016). Children are, in fact, agents, but they are not "super agents," we are wise to remember. None of us are.

In this article, I examine caring acts that have been marginalized in efforts both to uncover children's agency in care and to attend to their vulnerabilities and constraints in very difficult conditions. Such caring acts are fantastical, exaggerated, and counterfactual. The examples on which I draw include Gift, from the story above, flying to the hospital and loading his sister onto a balloon. They also include: a girl drawing a two-dimensional orange that rose off the page and into her mother's hands to be peeled and eaten; a boy sitting with his father in a hospital room to which he had no access; and another boy piloting a plane to South Africa. These fantasies are not quaint, they are not delusional, and they are not separate from more materially evident care. Fantasies are social acts (Weiss 2002) and, as such, children's caring fantasies provide vital insight into the care that has emerged within the intersecting regimes of global health and biomedicine.

Scholars in sub-Saharan Africa have used fantasy as an entry point into understanding the experience of large-scale global processes, such as colonialism and neoliberal capitalism (White 2000; Comaroff and Comaroff 2002; Weiss 2002) and, more recently, epidemiological shifts and the rise of global health projects that permeate daily life (Livingston 2005; Brada 2013, 2019). In my previous work, I have described the dominance of global imaginations of health and well-being in George - from the imagery promulgated by a World Health Organizationpromoted, donor-backed, and nationally supported TB control regime (Hunleth 2013a) and the rollout of no-cost antiretrovirals for HIV (Hunleth 2013b) to the anticipatory programming aimed at children affected by HIV (Hunleth 2017) and at universal primary school education (Hunleth et al. 2015). While other researchers have examined the fantastical in sub-Saharan Africa as populated by witches, vampires, and zombies, I turned in my previous writing to something far scarier, at least to the children I knew: the orphan. Orphan discourses, circulated by global health programs, had palpable effects on children, scripting for them a narrative resembling a fairy tale without the happy ending, where the death of a parental figure led first to exploitation, then to homelessness and the social death of the child (Hunleth 2017).

The fantasies I examine in this article build on this previous work and come from that same ethnographic project I carried out in Zambia on and off between 2005 and 2014 and, most intensively, between 2007 and 2008. That study of children's caregiving practices in the midst of epidemic TB and HIV took place 
in TB-affected households in George, Lusaka, and included thirty-eight children between the ages of eight and twelve who belonged to twenty-five households. I visited the children weekly in their households, and my research assistants and I engaged the children in the research through participatory methods such as drawing and child-led interviewing and storytelling. I also organized six participatory workshops that the children attended midway through and at the end of the study, where we played games, had group discussions, and the children acted out role plays of their own design.

In 2017, I published a book on this research, Children as Caregivers: The Global Fight against Tuberculosis and HIV in Zambia. After finishing the book, I expected my last piece of writing on the project to be the commentary attached to a digital children's art gallery I was developing as a visual companion to the book. ${ }^{2}$ The gallery would showcase some of the nearly one thousand drawings that children had made for me, a body of work that covered diverse topics, from caring for a sick family member to being cared for by family members, from deaths in the neighborhood to women's fashion and holiday dance parties. It also included objects encountered in daily life or on television and illustrations from school lessons. ${ }^{3}$

As my book was going to press, I pulled hundreds of drawings from my filing cabinet. The scents and the crayon-rendered images, the small and large fingerprints smudged across the once-white papers, and my own and my assistants' handwriting on the backs of the pages returned me to the people and the places of the research. I spent weeks with the drawings scattered in different configurations across my office desk and floor, trying to order them in a manner that made sense for the online gallery. As I did this, I rediscovered many fantastical tales that I had not fit into Children as Caregivers, including Gift's story, told above-a story I found both beautifully and frustratingly opaque. I went back through my notes to see if I had overlooked fantastical tales of care in other methods I had used. I had-there were fantastical stories, songs, role plays, interviews, and interactions throughout.

Later, as I talked to students in the United States who had read Children as Caregivers, I fielded questions that required me to recognize the presence and also, then, the absence of the fantastical in my writing. Students asked: How do you know if what the children were telling you was real? How do you get to the truth about what children do? Students' fascination with "the real" reminded me of the geographer Nadia von Benzon's (2015) argument that childhood researchers, concerned perhaps with issues of verifiability or overwhelmed by uncertainty and analytical messiness, have underreported and underanalyzed children's fantastical stories. And so I returned to a project that I thought was finished. "The people 
and places that we circle back to in the ethnographic endeavor-hence in space, time, and writing - are critical practices integral to the making of new forms of knowledge," wrote Angela Garcia (2016, 588).

Circling back in my thinking to Gift and to the other children led me to consider, in more detail, children's play-based, fantastical, exaggerated, and counterfactual renderings of care as themselves a form of care. I call this care imaginal caring. My phrase is inspired by Cindy Dell Clark's (2003) term imaginal coping, which she used to describe children's coping practices during their own illnesses. Imaginal coping includes, for Clark (2003, 94-95), a range of activities - play, stories, rituals, humor, prayer - that children engage in, often with others, to address problematic meanings that arise during painful treatments and disease diagnoses that alter daily life and future expectations. By introducing a new concept, imaginal caring, I am not arguing that the concept of imaginal coping is unsuitable for a study of children's caring for others, just that it would produce a different analysis, one focused more inwardly on children's knowledge and cognition. Unlike coping, caring is directed toward an external entity — a person, an animal, a thing - and more directly homes in on relationality and the provision of actions and sentiments.

I bring imaginal and caring together to suggest that, through their imaginal caring, children both expressed their care for others and were, in fact, providing care for these others and for themselves. This argument builds on dualities in the terms caring and imaginal. To care for can mean: 1) to provide for: to feed, to bathe, to house; or it can mean 2) to have an interest in or affection for another or oneself. ${ }^{4}$ That is, care is both a doing and a feeling and, while distinct, the doings and feelings of care are deeply entangled and difficult to separate (DeVault 1991). In Botswana, Julie Livingston (2005) showed that caring sentiment could be crucial to healing bodies and maintaining social persons. Frederick Klaits (2010) observed that doing for others presented the most marginalized people in society with a means of improving how others felt about them and, connected to this, the care provided back to them. The intersubjective, interdependent doings and feelings of care affirmed relationships and worked to preserve social and biological life (Ross 2010; Whyte 2014).

Imaginal, more than terms like imaginative, imagined, fantasy, or play, signifies another dual meaning that I wish to engage as it relates to care. First, I wish to consider the imaginal as indexical of T. O. Beidelman's $(1993,204)$ definition of the imagination: the way in which people envision and critique their worlds and also try on their "what ifs" and "construct other versions of existence besides those 
actually experienced." Second, I use imaginal to direct attention to the image as a vital datum for studying care (Stevenson 2014). In what follows, I focus on visual images children conjured through drawing, telling stories, or invoking word images laden with cultural meanings (such as medicine or fruit), as well as on the art of producing, playing with, and communicating through these images. By engaging with images, I decenter the privileging of voice that excludes from research people who are silent, silenced, or alternatively expressive (White 2000), including children. ${ }^{5}$ As will become clear, there were many times when children could not, in conversation, articulate what they wanted to communicate. The image, as a "language that expresses without formulating" (Foucault 1993, 36; see also Stevenson 2014 , 12) proved, perhaps, all the more powerful because of this. ${ }^{6}$

Building on the dual meanings encapsulated in the concepts of care and the imaginal, and bringing these concepts together, I show that children produced image-rich fantasies of performing care in the past, present, and future in an effort to elicit behaviors and feelings they wanted to produce in their kin. This was not an entirely altruistic act. As I have shown in my other work, the futures the children imagined for themselves were tied to maintaining social connections, which required the return to health of guardians. In this way, children's imaginal caring was speculative and anticipatory in a region where regimes of anticipation drive humanitarian programming (Adams, Murphy, and Clarke 2009). Their engagement with the imaginal transcended the limits placed on children by their bodies, their relations, and their social locations. It held magical qualities, as children conjured care out of and through images to push back against external and deeply unequal global power structures in a place where care, for both sick persons and children, was both critical for biological and social survival and difficult to accomplish.

\section{THE QUEST FOR CARE IN GEORGE}

George forms part of Lusaka's densely populated urban sprawl, home to roughly 130,000 residents. Some families have lived in George since the country's independence in 1964. Many more have moved in and out depending on employment, housing, and other life circumstances, including illness. HIV has woven its way into almost every aspect of life in George, and conditions of poverty exacerbate its effects, including its effects on TB. For the past fifteen years, biomedical therapies for HIV and TB have also made their way into day-to-day life, as George's publicly run health center designated specialized TB and HIV clinics. These clinics provide medicine at no cost, and governmental and nongovernmental activities extend out from the clinics to the surrounding community and households. 
I met Gift's grandmother, Mrs. Munkanta, in George in August 2007 at the health center's TB clinic. Just after Mrs. Munkanta's TB diagnosis, her family decided that she should move from the farm where she resided with her husband and grandsons to the family house in George, which they had owned since 1964, and where her grown daughter now lived. On the farm, Mrs. Munkanta's grandsons, eight-year-old Gift and fifteen-year-old Blessing, had been her caregivers. When her condition worsened and she was diagnosed with TB, which necessitated medications not readily accessible in the rural area, the family decided that Mrs. Munkanta and Gift should move to George. There, clinical access was easier, and Mrs. Munkanta's daughter (Gift's mother) would be able to monitor her care.

Mrs. Munkanta explained to me that, following her family's decision, she and Gift packed their things and boarded a bus. When they arrived, Mrs. Munkanta's daughter was not at home but in the hospital with Gift's baby sister, who had also been diagnosed with TB. "TB runs through our family," Mrs. Munkanta told me. The year before, her grown son and her husband both had the disease. Her son would eventually die (in 2008), with Mrs. Munkanta by his side at the family house.

The demands illness places on families in George are high, and children help meet these demands. Even in the absence of illness, children in Zambia are socialized to participate in household economies at a young age (Colson 1958; Hansen 1990). They carry out domestic chores such as cleaning, washing, cooking, and minding children younger than themselves. They run errands for adults, carrying messages to neighbors and relatives and buying food and other items from the markets and shops. When people are ill, children become involved in quests for therapy and care for family members. Notably, as in Gift's case, children's involvement is frequently confined to the domestic sphere and to domestic tasks, and they remain peripheral to family discussions on care and healing - what Africanist scholars have called "therapy management” (Janzen 1978, xviii).

Gift's family noted and appreciated Gift's help as much as they expected it, and they framed his move to the city in terms of a parallel quest: a quest to care for Gift by enrolling him in school_-something his grandparents were unable to do previously because of the demands of the farm, the chronicity of illness and scarcity of caregivers, and the costs involved in school attendance. Despite the removal of primary school fees in Zambia in 2002 as part of a global primary-schoolfor-all movement, the costs of books, shoes, and a uniform remained substantial. Meanwhile, the increasing global and national attention to education fueled children's and their guardians' dreams for brighter futures. These combined factors- 
the cost of schooling and the importance it held in the social imagination - meant that schooling was not only highly valued but that sending children to school was an act of care that affirmed an adult's love for and commitment to them.

The day Mrs. Munkanta told me about the intertwined quests that landed both grandmother and grandson in George, Gift was seated on the floor next to me, telling a different story of moving to George, one propelled by flight: this is the telling with which I began. I had not prompted Gift to draw the sequence of images he did that day. Instead, I had given him crayons and paper during this first meeting without any instructions other than to draw anything he wished to draw. It was something I did during my first meeting with each child as a way to acknowledge the child's role in my study, and to get him or her accustomed to methods we would use.

Gift's caring quest was imagistic: it was grounded in the pictures he had drawn, the objects of the deflated balloon and the homemade bow and arrow he brought out for show, and the physical stances he took as he enacted the story. His quest was fantastical - a hero's quest that defied laws of gravity and the power constraints that eight-year-olds face.

\section{A PLAYING MATTER}

Despite timeworn observations of children imagining themselves as doctors, at least in Western contexts, little research exists on children's imaginative acts or play in caregiving. Jo Aldridge $(2008,261)$ critiqued this deficit, in part by calling the literature on children's caring "all work and no play." Imaginative acts have not been so marginalized in research with sick children. Cindy Dell Clark (2003), for example, observed in her U.S.-based study of children with diabetes and asthma that children engaged with play and metaphor as part of treatment - a syringe became a zebra, a stuffed tiger a protector. The healing power of this retreat from "fixed, literal representations" of cultural material, Clark (2016, 176) argued, was in "freeing up constraints upon subjunctivity." Cheryl Mattingly (2006) worked with African American families with children who had life-threatening illnesses. She described the prevalence of global images, such as Disney characters, in clinical encounters. Through invoking and playing with such images, children, parenting kin, and clinicians from different backgrounds managed to create a "shared imaginative space" (Mattingly 2006, 495) in fraught clinical encounters. Taken together, Clark's and Mattingly's work identifies the temporally inflected and communicative aspects of children's imaginative acts and the images they invoke and 
play with during their own (or others') illnesses (see also Bluebond-Langner 1978; Buchbinder 2008).

George is a far distance from the hospitals and houses in which Clark and Mattingly worked. To moor children's imaginative acts to the time and place in which they occurred, I offer a brief overview of play in George and how children and adults valued play and the capacity to imagine. To play proved central to what it meant to be a child in George. Young children made toys from things they collected; younger and older children played sports and other games they invented; and children of varying ages recounted and remade stories passed down from older generations. Children relished neighborhood drama. They followed, often literally, emerging goings-on and misdeeds, reporting these back to children and adults, while filling in holes in the narratives or reenvisioning and critiquing the outcomes. Gift once described to me a scene he encountered at a communal water tap after several women had found a fetus. In his account, he named the baby, brought her into his house, and raised her as his own.

Children's imaginative play took them outside of George, as they piled into houses with working televisions and electricity. During 2007 and 2008, children were captivated by a Filipino soap opera, It Might Be You, with a rags-to-riches story line and an orphaned character. Unlike the figure of the orphan from global health discourses, a character children described as devoid of a future (Hunleth 2017; see also Henderson 2006), the beautiful female lead triumphed over childhood misfortune, falling in love and finally marrying a wealthy man. Boys watched John Cena, an American wrestler, and they invoked his presence in their play. Beyond Hollywood, Bollywood, Nollywood (Nigerian cinema), and other cinematic and sports industries, children were avid consumers of global health and humanitarian productions. They tracked the comings and goings of nongovernmental organization vehicles and workers, and they were prominent attendees at educational dramas, concerts, and other events put on for adults. The workers and the events they organized spread globalized discourses on a range of topics - including childhood, education, public health, and medicine-providing all sorts of fodder for children's imaginations.

Adults in George did not engage in activities of mutual pretense with children to the degree that middle-class adults in the global North often do. Still, they viewed the capacity for children to engage in imaginative play and to fantasize as important to a good childhood. Adults referred to children they knew who did not engage in play using adult terms - "the mother of the house" - to judge the children's kin and/or assess a desperate situation. Gift's uncle once explained to me 
the importance of a television, which they did not own, for a child's development: watching television provided the child with the content they needed to imagine life beyond George. He worried aloud that Gift might have very limited views of his future possibilities without such content. Adults and children alike considered a good parent or guardian as someone who gave a child time to play and also imagined with and for that child. Much of this imagining was geared toward constructing better versions of reality based on their - the child's and the adult's own desires and aspirations, something that Beidelman (1993) called the "moral imagination." That is, it was relational, empathetic toward the needs of the other, and also deeply personal.

The centrality of play and imaginative acts in George prompted me to consider play as a way of doing anthropology. The activities I used_-drawing, storytelling, and role-playing - responded to the setting and context I just described. They fit well within children's everyday lives and were easily accepted, even encouraged, and sometimes participated in by the adults in the children's lives. Play, however, might best be envisioned less as an activity and more as a mode, as Helen Schwartzman (1979) has, in which a person adopts a contextual orientation toward something, which produces a text distinguished by allusion, distortion, and purported imitation. Play as a way of doing anthropology can serve as a form of listening that compels us to attend to and contextualize what Schwartzman (1979, 330) has called "texts." Texts, as I understand the use of the word in Schwartzman's definition, can take different forms, and they can be quite fantastical and also imagistic.

The imagistic evidence I present in this article includes many drawings that children made during my visits to their households and many more that they made between my visits, something I had neither anticipated nor, at first, encouraged. And even though I introduced topics, such as "draw yourself taking care of a sick person," many drawings I discuss in this essay were made without such direction. Readers might note at this point that the creative methodologies I used introduced new persons, objects, and spaces, and these compelled the children to respond creatively. But this does not reduce the validity of the images and imaginings produced; instead, it adds another line of evidence (von Benzon 2015). Whether we are working with children or adults, relying on drawings or ethnographic interviews, people will always respond to the methods we use and the materials and people we bring to the field (including ourselves). The creative uses to which children put my research, I have suggested, are informative of broader tactics that the children employed because of the constraints they faced (Hunleth 2011). 


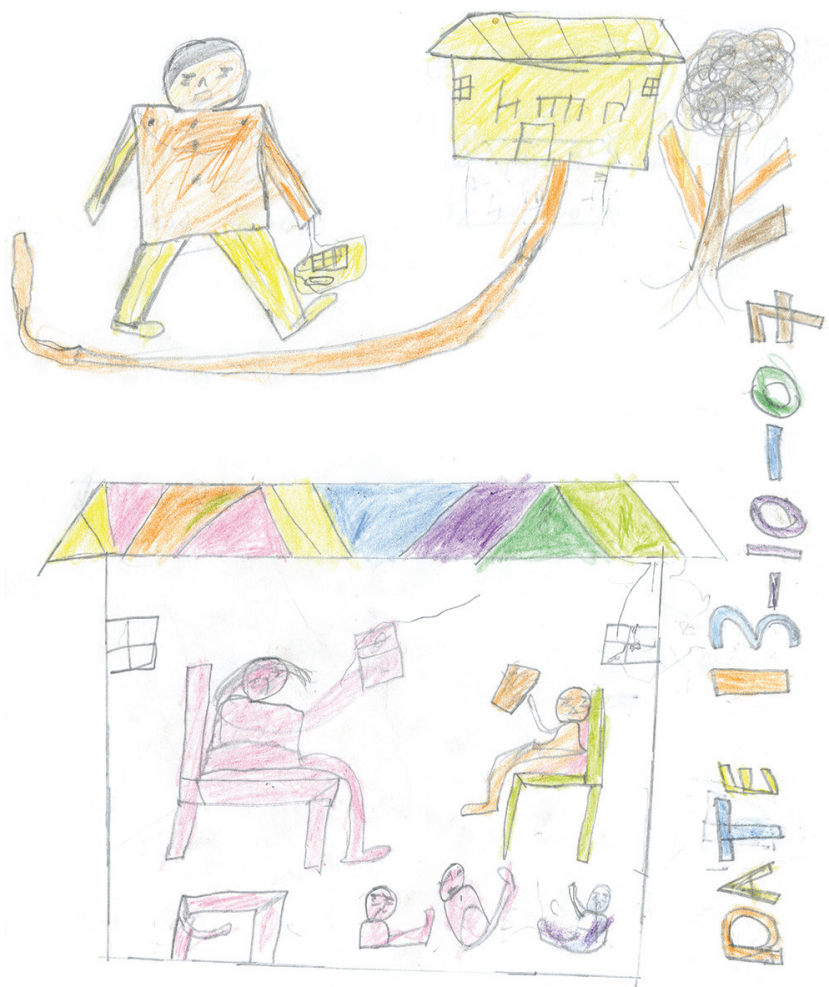

Figure 2. The author and her research assistant, Emily Banda, in Alick's house, listening to Alick and his siblings talk about their drawings. Alick drew his father coming home from work at the top. Drawing by Alick Katongo.

I do not think that the image in imaginal caring is limited to drawings, and other examples come to mind that I do not mention at length in this articledreams, songs, stories, and word-images (e.g., Gift's invocation of blood in the following section). However, I have, both consciously and unconsciously, focused on the drawings in writing this article. The drawings, it seems, have their own power over me. They are witness to the deeply interpersonal experience of ethnographic research: they connect me to children who are now grown. They are testimony, too, to the lives of a number of adults and one child who have since died. I have taken them out for weeks at a time, and I have hidden them from my sight. I purposefully left them out of my published articles and then, when I was about to move on in my scholarly work from this particular research project, I obsessed over their invisibility and curated an online art gallery. Michael Taussig (2009) once asked: "What do drawings want?" I have over the years asked the same question, though increasingly I have asked this in a more personalized tenor: what do 
these particular drawings want from me? Mine is a question born of frustration (why have they not let me go?), and also of care.

\section{HOW TO DO THINGS WITH DRAWINGS}

I met ten-year-old Abby in 2007 on the day that her mother, Elesia, learned that she had TB. In the morning at the clinic, Elesia had asked me to come to the house to meet Abby and to go over the consent forms for my study in more depth. When I arrived that afternoon, the sitting room was filled with extended family members who had formed an impromptu therapy-management group (see Janzen 1978) after hearing the news of Elesia's TB. Elesia sat quietly, curled up on one end of a couch. Her family members and I surrounded her in a circle of chairs. Abby stood behind a chair opposite Elesia, peeking out to watch her mother and also get a good look at me, the stranger in the house. I reached around the chair to offer her a packet of crayons and paper, an offering I hoped would be read as acknowledgment that I wanted to hear her perspective even as the adult talk pulled my attention away.

Back across the circle, a family member explained to me the direness of Elesia's situation, and I listened to the family debate possible care scenarios, which did not include Elesia and her children staying in their current housing situation - a sparsely furnished rental of a relative who was a bus driver "on ARVs" (antiretrovirals for HIV) and rarely at home. His maleness, his job, and his own health challenges made him a less-than-suitable caregiver for Elesia and her children in the eyes of the family. Although Abby and her younger sister had already been taking care of their mother for weeks prior to the diagnosis, there was an unspoken acknowledgment that they, too, were unsuitable caregivers given Elesia's expanded care needs, the contagiousness of TB disease, and the girls' young ages.

During the conversation, Abby drew, responding on the page to the debate occurring in the room. The adult conversation ended with a plan. Elesia would go to her sister's house across Lusaka, and Abby and her sister would go to the family house in George where their uncle currently lived. This decision would separate the girls from their mother for the first time. Excluded from the circle and the debate, Abby drew a cooking pot, a schoolbook, a beer bottle, and an orange. When the family discussion had ended, I asked about her drawings, with the family still seated around. She whispered: the pot, it was for cooking for her mother; the beer bottle, it was for her father, who "likes beer," an indictment of the man who had kicked them out of their house (also drawn) the week prior, which had caused her to stop attending school. The schoolbook was a schoolbook, without further 
explanation. The orange, a fruit known for its health benefits and also a rarity in households in George because of its price, rose off the page. Abby told her mother that this was an orange "for her."

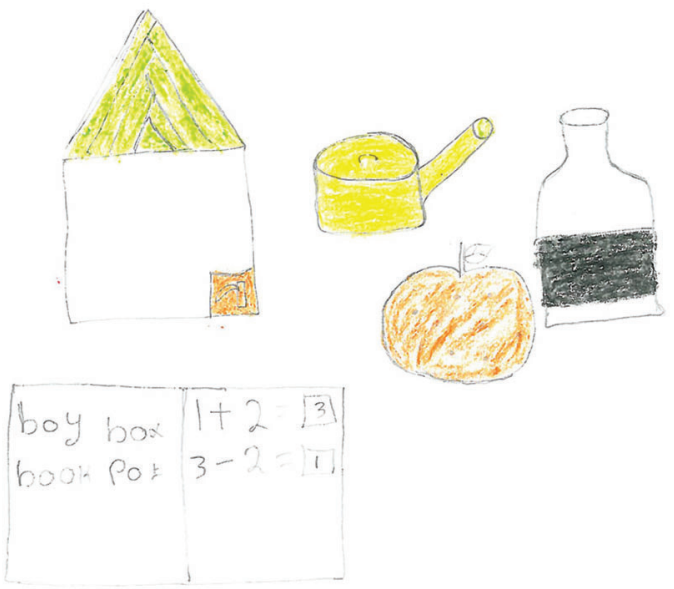

Figure 3. Abby drew these images while her family members debated how and where they would care for Elesia, Abby's mother, who had been diagnosed with tuberculosis earlier that day. Drawing by Abby Banda.

A person who draws, in Taussig's $(2009,265)$ terms, is a "maker-viewer," whose drawing is "at once intimate and personal yet bears the obligation to make something that exceeds the personal.” Taussig $(2009,265)$ calls this a conversation "between the drawer, the thing drawn, and the hypothetical viewers." I would add that when drawn in front of an audience, this conversation includes, also, very specific, nonhypothetical viewers. I am reminded of D. W. Winnicott's (2005) suggestion that play — in this case, drawing as a form of play — can conjure a transitional space of creativity and communication. Within this space of creativity and communication, a drawing, to use Taussig's (2009, 271) words again, might provide a "zone of mediation" and also a "means of getting close to" the object drawn.

After knowing Abby for some time, I came to appreciate how much she was doing in and with the drawings, and I gained a partial understanding of her motivations. She combined images of performing care and forestalling care, love and hate. The magic of the cooking pot and the orange were not their visual similarities to these objects or that she knew what she was supposed to do with them. The 
magic was that she was able to get into the page to become the cook she wanted to be, and that she was able to pick the orange off the page to give to her mother. Was the drawing specifically intended to influence the debate occurring in the room at that moment? Perhaps. Yet Abby was aware of the limits to her control over her situation, limits that did not exist in drawing. And while her mother and her other relatives could still overlook, minimize, or reject Abby's desire to live with and provide care to her mother, the drawings of care - the orange, the cooking pot, and even the schoolbook - circulated in that room as visual reminders that she both cared for her mother and was herself in need of care. Months later, her life still beset with uncertainty, Abby drew her father's bed with a rat under it - a rat specifically made for him. Her father, she said, had a "bad heart." One can send love through an image; one can also send hate, rendering visible feelings that held the potential to heal or to harm. ${ }^{8}$

The images drawn to heal blurred the line between fantasy and reality. On a different visit with Gift, I asked him to draw "caring for a sick person." As he was making that drawing, he whispered, "So much blood. So much blood." These remarks stopped us — his grandmother, Emily (my research assistant), and memid-conversation.

"What blood?" Emily asked as we examined his drawings for clues.

The blood, we learned, referred to a neighbor's bludgeoning death. The death occurred seemingly at random right after Gift had moved to the city. It was a disquieting introduction to the city neighborhood that prompted Gift to worry about the safety of his family, especially that of his sister and grandmother. Among other material and existential threats, illnesses required the family to unlock their doors at night to go to an outdoor toilet for bouts of vomiting or diarrhea. After the neighbor's murder, Gift practiced fighting (on and off the drawing page) and fashioned a bow to protect his family against intruders, the same bow he imagined using to kill an imaginary snake that threatened his sister's life in his earlier drawing.

Alongside the blood, Gift called up another image: that of mobile phone parts scattered across the dirt road in front of the house. The day after the murder, the neighbor's family discarded parts that the man had used for his phone repair business. Most passersby did not wish to touch the parts because of their associations with death, paired with their own imaginations of the misfortunes that the possession of such items might bring.

As the first person to claim the mobile phone parts, Gift felt some fortune in this tragedy. He sold the parts at the local market and in the neighborhood. With the money he made, he bought food and drinks for his baby sister. For a brief 
moment, Gift had purchasing power to bring a highly valued aspect of caring into existence.

Lest we oversentimentalize such caring, I offer an interlude of the children's dramatic role plays of living with a sick person. I call it an interlude because I do not view children's role-playing, which I initiated during workshops held away from family members, as imaginal caring. I never witnessed children role-play care with peers spontaneously in their households, or with parents or guardians as their objects. Because children participated in the concealment of TB and HIV from peers and within their households and because they avoided certain types of play near sick adults (Hunleth 2011, 2017), role-playing care with peers in the presence of a person who needed care might be interpreted as counter to efforts - imaginal or otherwise - to give good care. Even though the role plays are not examples of imaginal caring, they offer critical insight into the political-economic context and the stakes of caring, while staying focused on the children.

\section{INTERLUDE: Playing the State}

Water!

Medicine!

Give me a blanket!

Blanket! Blanket! Blanket!

From stage left, a sick man gave commands to his wife and two children in the opening lines of a role play created and performed by eleven-year-old Stephen and three other children. This was one of twenty-one role plays that took place across six children's workshops I hosted in George with the same children who participated in the household research. The theme of the play was living with a sick person, which was the only guidance I gave the children before they created it. Stephen played a sick man who had TB, much like his father at the time of the workshop.

"Blanket!" was Stephen's last spoken line in the role play- his speech undercut by the severity of his illness. Following this final command, the child playing his son arranged his shirt; the daughter covered him with a pretend blanket; and the wife decided that they should see a doctor.

The four children crossed the room to the fictional clinic and waited for the doctor. They waited for so long that it became time for Stephen to take his medicine, which was still at home. The wife directed the daughter to run back to retrieve it, and they gave the medicine to Stephen when she returned. More time passed, and the wife sent the son home for a blanket. They waited. 
When the doctor still had not come, the wife asked the siblings to help her carry Stephen back home. A child in the audience interrupted their journey across the room, yelling out: "Take him to the hospital." Responding to this command, the group changed course, and headed toward a different corner of the room.

"Why is he walking [to the hospital]? Take a taxi," another child shouted. This time, instead of responding to the audience member, the actors kept walking, holding Stephen on either side until they arrived at the hospital. Perhaps even in their imaginations, the family could not afford a taxi.

Once at the hospital, the family waited.

"Even here there is no doctor!" A child in the audience exclaimed, and the family headed back to their house, where they continued their watch over Stephen.

Time passed, and the daughter went back to the clinic without Stephen to collect more medication. "Medication for what?" an audience member asked. "TB," the daughter replied. She returned to the house and gave Stephen the medicine.

"He's not getting better," another audience member shouted, prompting the family to take Stephen back to the clinic. Again, the doctor did not show up. Frustrated - either with the audience for continuing to point out the futility of their efforts or with the course of the role play - the child posing as Stephen's wife ended the role play, announcing to the audience that "he has recovered."

In this role play, clinical surveillance and care coexisted with abandonment. State care was given through medication, emblematic of what João Biehl (2007) has referred to as the pharmaceuticalization of public health. I have written previously of how various global and national actors proclaim treatment as the key to recovery, a message that the children embraced and also transformed to cultivate caring actions and sentiments between themselves and specific adults (Hunleth 2013a).

In all play, rules of behavior exist in concealed form (Vygotsky 1967). The actors showed some rules of care for the family: stay present, give food and water, get medicine from the clinic, give medicine, observe closely the timing of specific caring activities, and go to the clinic when the person is not recovering. The audience members made explicit other rules and lodged judgments at the family: "take him to the hospital"; "take a taxi”; "he's not getting better." Like the audience members, onlookers from families, neighborhoods, and clinics make judgments about the sentiments and actions of caregivers. Judgments about care become fodder for blame and debates about persons' "hearts," which extend beyond illness and into death. 
The above role play recalls another play at a separate workshop, with different children from the study participating. Again, all four children acting out the play came from households where a family member was currently suffering from TB. Abby, whom I introduced in the previous section, began that role play with loud coughing, prompting her character's daughter, played by Agnes, to take her to the clinic for a diagnosis: TB. Agnes collected medication from the doctor and gave it to Abby at their house.

Because Abby was not recovering, despite the daughter's dedication, the daughter began to consider a possibility: "You want to kill my mother," Agnes shouted at the doctor. She and her father dragged the doctor to the local police station and had him imprisoned.

With the doctor in prison, father and daughter were in a bind. Abby needed medicine, but there was no one at the clinic to hand it out. They returned to the police station and had the doctor released, warning him to "do better."

Once out of prison, the doctor created more confusion. He even prescribed kachasu, a distilled liquor, that TB patients are warned against drinking. Fed up, Agnes chased after the doctor to beat him up. He narrowly escaped and the play ended.

How might we interpret a scenario in which the clinic provides medicine but the doctors never show up? Or one in which a child plays a doctor who wants to kill his patient? These were stories that circulated in George in various forms. However, as with children's play in general (Schwartzman 1979), it would be inaccurate to suggest that children's play_ or role play — was either simplistic imitation of such stories or mere illusion and distortion of the social world. ${ }^{9}$ Like the stories of vampires that Luise White $(2000,89)$ analyzed to reconstruct African experiences of colonial medicine, such fantastical accounts, including in role-play form, "describe meanings and powers and ideas that inform how people thought and behaved."

Children experienced the collective concerns, frustrations, and uncertainties with illness and medicine from a position of relative powerlessness in their households and in the clinic. Role-play gave them the opportunity to play with and invert the structures of power that constrained their usual engagements. Perhaps that is what made the second role play so comical - maybe even freeing - to audience and actors alike, who laughed throughout, as the doctor made explicit his intentions to harm and the daughter sought revenge. 


\section{AGAINST ISOLATION: On the Road, in the Sky, and at the Bedside}

An image is imprinted in my memory from my work with the children. It is reinforced as I look through the drawings that the children made, both on my suggested topics and initiated on their own and in my absence, without direction or guidance. This image is of a child and her sick family member walking side by side, and hand in hand, to and from the clinic or hospital. I see ten-year-old Annie holding her mother's hand on her way to get her mother's TB medications and ARVs. I have an image of Paul and his father on the side of the road, waiting for a minibus to take them the partial distance to the clinic, shortening what would be a two-kilometer walk. I also have an image of them taking a different route, this time on foot. I picture Stephen and his father on the side of a road, holding hands on their way to their house from the University Teaching Hospital (UTH). I even visualize Gift holding his baby sister as they float on a balloon that takes them away from the hospital. ${ }^{10}$

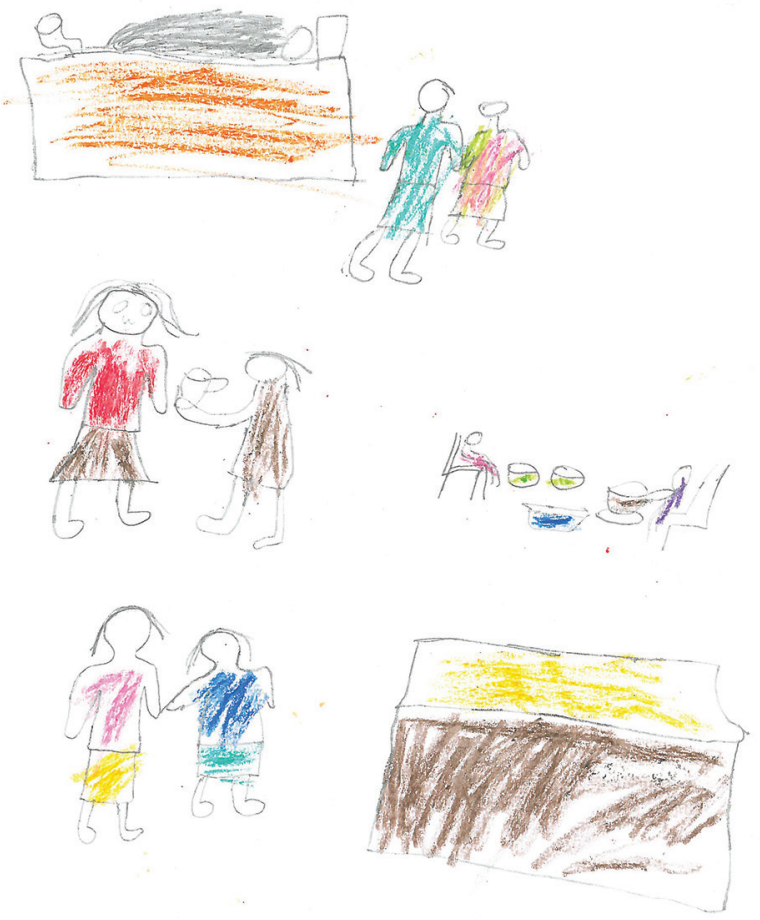

Figure 4. When asked to draw herself taking care of a sick person, Annie depicted the following scenes of herself caring for her mother (from top): taking her mother outside to vomit, giving her mother medicine, eating with her mother, and accompanying her mother to the clinic. Drawing by Annie Nkhata. 
These and other images come to me so vividly that, over the years, I have questioned my memory; maybe some of the less fantastical scenes occurred, though they likely did not, based on all my available evidence. The TB ward at UTH was not a place for children - with its warnings about contagion and the necessity to keep space open for staff to move around amid the overcrowding. Other TB-affected spaces, such as the TB clinic in George, were more proximate and open. Yet adults who controlled these spaces were wary of children in them and did not approve of their presence. When younger children entered George's open-air TB clinic on their own, they were told to go home. Or so clinic workers told me. I rarely saw children there and, when I did, the children seemed to understand not to breach the inner area. Spaces designed with children in mind, such as schools, camps, and children's hospitals embody idealizations of children, and these idealizations hold political and affective power (Brada 2019). The management of the TB epidemic in Zambia shows that spaces designed for adults can also embody idealizations of children that hold political and affective power. These idealizations came up against the children's own visions of their roles in propping up the biological and social lives of family members who were sick.

Being hospitalized and visiting the clinic presented risks for sick persons. People in George recognized these risks in their talk of persons they knew who had died coming to the clinic, shortly after returning from it, or while hospitalized. The journey was taxing; it could wear a person's body down. Beyond the physical exertion it took, family members worried that a person making such a journey might lose hope under the ambiguous gaze of bystanders. They would cover the sick person's face, at times, to protect against onlookers. The power of the gaze should not be underestimated, something that Annie's mother emphasized to me when she said that children's proximity prevented sick persons from succumbing to the potential evil others might wish on them, and to which they were more susceptible in their weakened state. Protecting a sick person from the gaze, then, itself constituted a form of care in George.

Once at the hospital, families had significant, substantiated worries about the provision of good care. Drugs could run short and waits for diagnoses and treatment could run long. Family caregivers who stayed in the hospital through the duration of admittance, known locally as bedsiders, were an acknowledged, though unofficial, part of the hospital system, helping hospitals monitor patients and meet patients' day-to-day needs. Hospital staff worried about the well-being of patients who did not have suitable bedsiders or whose family had abandoned them. Not only did bedsiders accomplish much physical and emotional work for patients and, 
thus, for hospitals but they also provided a link to the sick person's family and community needed for their return home. ${ }^{11}$

If we only looked in hospitals and clinics (and along the routes to them) for acts of accompaniment and bedsiding, we would miss a lot. When Luka's father was in the hospital, Luka asked to use my audio recorder in private. Speaking into the recorder, he explained that he was not allowed on the ward and that he felt tired. He then described a fantastical plot to scale the brick walls of the hospital and climb through a window and into his father's ward, so that he could see him and give him medicine. But he recognized, aloud into my recorder, that the building was too tall to climb and that, anyway, the doctor would not allow him in. Luka then proceeded to hold an imagined conversation with his father's doctor, the same doctor who had refused to let him on the ward. He implored the doctor to take care of his father because he and his brother, Paul, would not "be coming to see him with medicine every day in the morning before he eats anything." While Luka discarded his fantasy of scaling the hospital building, his request also held moral force (Klaits 2017). The fantasy and the imagined request, spoken into my recorder, verbalized his commitment to his father and made known his father's needs. Both risked elision within the medical system.

Though Luka did not see himself getting into the hospital, a number of children envisioned themselves as bedsiders. In between my visits to Steven's house and without my prompting, Steven made a detailed drawing of himself bedsiding for his father when his father was admitted to the UTH. He included images of his father's IV drip and medicine in this drawing, relying on his mother's accounts of what she saw and did to achieve accuracy. Other children presented drawn accounts of loved ones' hospitalizations well after they occurred and included themselves in the images. Through the acts of creating and showing such drawings to loved ones, their imaginal (bedside) caring was brought into existence and served as a form of assertion, one that told family members: "I have not stopped caring for or about you." The messages conveyed through the drawings also said: "Recognize me, I am here."

\section{ANTICIPATING THE FUTURE: Of Buses, Planes, and Houses with Stairs}

The children held onto idealized versions of the future, in which they were able to complete their schooling and achieve financial independence or, in Abby's terms, get a good job and a house of one's own. To achieve such a position of social adulthood, they needed monetary, emotional, and social investments from 
relatives while young. Abby described it this way: A child who is given what they need when young will grow up to have a good job and a house. With such financial independence, they will be able to keep and care for dependents by sending them to school and giving them everything else they need. She elaborated that this was important "so that [the child dependents] also get an education and take care of you [when you are old].” To summarize Abby's ideas using Parker Shipton's (2007, 11) words, a lifetime was built on a series of entrustments returned either "in kind or in radically different form."

Illnesses, particularly of parenting kin, siblings, or close family members, cast normative ideals of dependence and independence throughout the life course in an uncertain light. Recall Luka, who imagined scaling the hospital building. Luka's brother, Paul, was eleven years old when his father first became ill. In Paul's, Luka's, and their parents' imaginations, Paul was going to make it out of poverty and take his family with him. I learned of his aspirations early on when I asked Paul to draw himself caring for a sick person. In his drawing, Paul drew himself

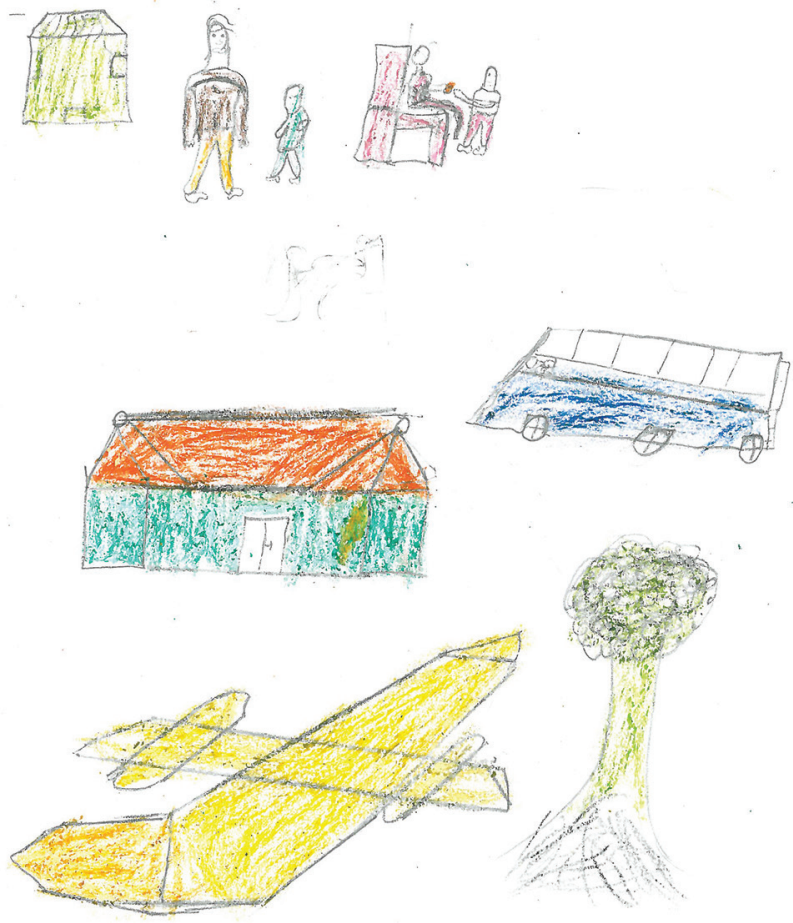

Figure 5. When asked to draw himself taking care of a sick person, Paul drew himself giving his father an orange that he had bought to help his father feel better. He also drew himself accompanying his father to the clinic. At the bottom, he included a drawing of his airplane, the one he used to fly passengers from Zambia to South Africa. Drawing by Paul Kangwa. 
giving his father an orange and accompanying his father on foot and by minibus to collect medication. At the bottom of the page, he drew an airplane.

The airplane on the page was his airplane, and he was flying passengers from Zambia to South Africa as a pilot for Zambian Airways. With pride, his father, who was listening to our conversation, explained to me Paul's desire to become a pilot. In the process, he invigorated Paul's dream and reaffirmed its plausibility. While Paul acknowledged that his father could not monetarily contribute to his future development at present, he confided into my recorder on a different occasion that he intended to ask his father to buy him a new school bag when his father recovered - the promise and image of a new school bag acted as a form of care. ${ }^{12}$

Luka also drew Paul's airplane in his drawing of caring for a sick person, tying his own future to his older brother's future. It is possible that he expected to make sacrifices for Paul's success, something not uncommon in their area, where resources are limited and where some siblings are expected to work to put others through professional schooling. A successful sibling would not-or should notforget the siblings who helped along the way, promoting the well-being of those

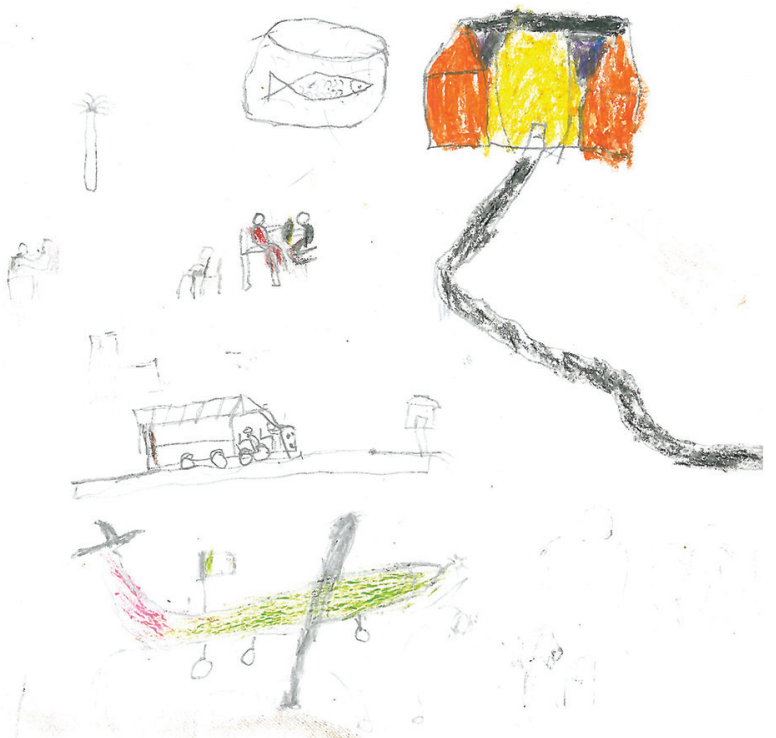

Figure 6. Luka featured Paul's airplane in his own drawing of taking care of a sick person. Luka also drew a fish for his father to eat and scenes of giving his father medicine and taking his father by bus to the clinic. Drawing by Luka Kangwa. 
siblings and their families by providing housing (as Gift imagined doing for his sister), money, food, and funding for their siblings' children's schooling.

The appearance of Paul's plane in the boys' care drawings raises questions: Was Paul simply filling up the page or drawing things he knew how to draw? Was Luka emulating his big brother? Were the boys shifting the conversation away from illness? I do not have ready answers for these questions. However, one answer seemed to surface five weeks later when Paul gave me an unprompted drawing when I visited his house, shortly before his father was hospitalized with pneumonia. The drawing resembled his previous drawing of care, in which he also imagined accompanying his father to the clinic. The clinic, however, was more prominent in this version, and the plane had moved to the center of the drawing. It was situated between the clinic and the family's house, presenting imaginal ac-

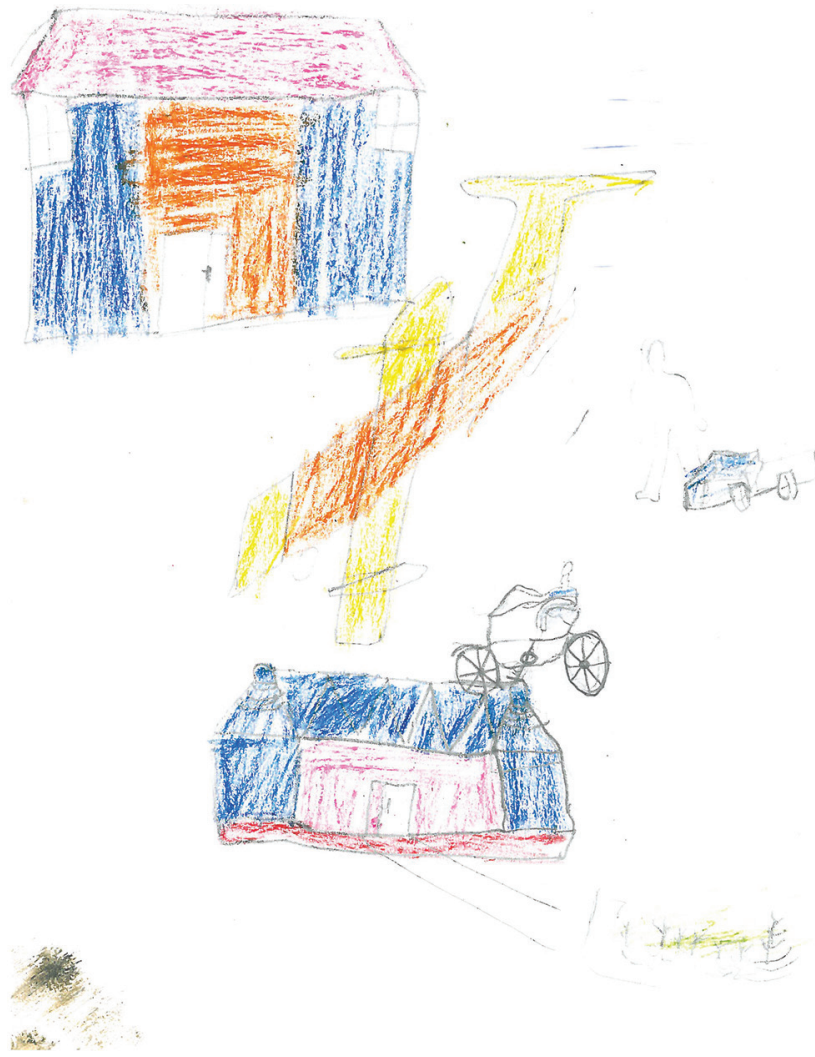

Figure 7. Paul made this drawing five weeks after drawing himself taking care of a sick person (see Figure 5). He drew on his own, instead of responding to a drawing prompt, and presented this drawing to the author during a visit. While it resembled his previous drawing of taking care, there were several differences. Notably, the clinic and his plane were more prominent, and the latter plane was in the center of the page. Photo by Paul Kangwa. 
companiment and imagined future side by side — the present and the future folded together.

The disruption caused by Paul's and Luka's father's illness, alongside growing concerns that their father might die, seemed to have threatened Paul's imagined future as a pilot, an already precarious dream given the depths of poverty endured by his family and the shortages of social resources and formal-sector jobs in the region.

It is worth pointing out that during the time Paul made this second plane drawing, his father was openly considering death as an alternative to suffering. Paul believed that his father wished to stop taking his medicine and was giving up on living, and he was attempting to counteract his father's sentiments and actions. One way he did that was by invoking the future — without TB, without pain, and with financial security. I understand the second plane drawing as part of these efforts. Paul drew the plane without my direction; he presented it to me in the presence of his father when I made my weekly visit; and he used it as a tool to redirect the conversation during my visit to talk about his future. Paul was not just speaking to me, but to his father through me, as he had done during past visits when he symbolically gave his father fruit from his drawing pages.

I view Paul's drawing and related conversation, in part, as a creative measure to gain power within and control over illness, his father's extreme suffering, and his own uncertain future. Paul played on and also with his dream of becoming a pilot and the normative notions of children's future caring responsibilities to parents. He engaged in a process of retemporalization, where the future becomes an intervention into the present (Chua 2011). Public health efforts hinge on such processes, as patients are asked to anticipate better health and better lives, and children are encouraged to go to school to anticipate better futures. Here, I point out that such regimes of anticipation (Adams, Murphy, and Clarke 2009) are not unidirectional, but that Paul, and other children, were actively using them to encourage the types of behaviors and emotions they wanted to produce in their guardians. They were doing so not just for their guardians but also for what their guardians' life and death meant for their own potential lives and their own futures.

\section{CONCLUSION}

Just as I was preparing to submit this article, I received a message from a friend from Zambia, a nurse who had worked in George. She and I had lost touch in 2008, and we ran into each other by chance in May 2018 at the UTH, where she now works and where I was visiting to set up a new study. She has since kept 
in regular touch by sending me inspirational messages several times a week via the messaging app WhatsApp. The message she sent this time was a joke:

An old farmer wrote a letter to his son who is in prison. "Son, this year I will not plant cassava and yam because I can't dig the field. I know if you were here you would have helped me."

The son replied to his father, "Dad, don't even think of digging the field because that's where I buried the money I stole."

The police and prison on reading this letter went early in the morning and dug the whole field in search of the money, but nothing was found.

The next day the son wrote his father again. "Dad, you can now plant your cassava and yam, this is the best I can do from here."

Dad replied, "Haha, my son, you are too powerful indeed, even in prison you still command policemen to work for me. I was so surprised to see the IGP [Inspector General of Police] and his team holding hoes and shovels, digging my farm. I will write to you when I want to harvest."

MORAL LESSON: Nobody can imprison your mind.

I take a somewhat different lesson from this exchange, which is that constraint and separation demand creativity. While the son's success certainly adds to the humor and appeal of the joke, my goal is not to claim that children are successfully overcoming their limitations. Instead, it is to show how the economic, moral, and imaginative dynamics of care are played out in children's efforts and relations. Acknowledging and writing about children's fantastical, exaggerated, and counterfactual stances within illness does not trivialize children's social acts, make light of their marginalization in society, or ignore the desperate situations in places like George. Likewise, it does not replace a focus on other forms of care that children also gave out of love and necessity, and which were demanded of them by others or because no one else was around. There is sufficient evidence, including in my own research, to show that children do a lot of the things we (as outsiders, as global health workers, as anthropologists) consider under the rubric of care work. But what I am arguing for is not an either/or. To suggest that fantasy is not real would, of course, be false. Rather, my suggestion is for an expansion of the evidence used to examine how people give care, especially under severe constraint. In George, there were high social stakes for children (and almost everyone) in not doing care for others. Not doing and not feeling removed a person from the social. It scripted dark future possibilities that children went to great lengths to avoid, 
including through the images and fantasies they invoked, created, and with which they played.

Did the children think they were doing the things they imagined-flying, creating consumable fruits, sitting in the hospital, walking to the clinic? As much as this question seems to surface for audiences of my work, it was never a question I thought to ask during the research. I assume that, had I asked, the children would have answered, "no, those things are impossible," much like Luka, who corrected himself aloud when he considered climbing the hospital wall. But this question and the answers to which it leads us miss the point. Recall that Luka did not finish his story with the impossibility of scaling the wall — a rejection of fantasy — but with another possibility, as he implored the doctor to stand in for his absence.

Part of giving care and also receiving care back, for the children, was doing things to make others act and feel: parenting kin who were sick, doctors who served as gatekeepers, and family members who had other notions about the direction of care for a sick person. As I have shown, children could not stay with kin in the hospital to ensure that the doctors attended to them and that their kin's needs were met. They could not always accompany sick persons on the path to the clinic, picking them up when they fell and warding off the ill intentions and curious gazes of onlookers. They were not able to "do anything the sick person wants," to use Nancy's words, a defining feature of good care. And even when they could, family members and sick persons did not always respond in desired ways, either in their actions or through bodily change. These are some of the areas where imaginal caring, as I have discussed it, held possibilities as a way of providing and performing care, an intervention into the present with implications for the future.

Everyday acts and expressions of care take form within broader regimes of care. Ethnographic research shows that current regimes of care fall short in providing for the needs of persons who are sick and, further, that individuals and their families must somehow make up for these shortfalls. As Susan Reynolds Whyte and colleagues (Whyte 2014) found in their work with members of the first generation of Ugandans with access to HIV treatment, care (given and received) was what distinguished between life and death for people on ARVs. Relationships are vital, and people, especially those most marginalized and constrained by status, identity, and economic means, must devise creative ways to compel others to listen and respond to them. There is imagination within all such creativity. Perhaps, then, imaginal caring is not so uncommon in the world and, if we attune ourselves to it, we might just find that, in our efforts to give and receive care, we are all drawing our imaginary airplanes. ${ }^{13}$ 


\section{ABSTRACT}

Based on ethnographic fieldwork in Lusaka, Zambia, this article puts forth the concept of imaginal caring to examine a form of caring that is fantastical, exaggerated, and counterfactual. To develop this concept, I take the vantage point of young children (ages eight through twelve) who lived in households with persons who were suffering from tuberculosis and HIV. The children were involved in providing dayto-day care in many ways. They were also constrained in their efforts to give and show care because of their social positions, their access to resources, and their small human bodies. Through a series of examples, I demonstrate the ways in which children created and played with often visual images of giving care to family members in the past, present, and future. I show that fantastical imaginations and images of children's involvement in caring not only expressed that they cared for others but also served as ways for them to provide or perform care. There were high social and personal stakes for children in not being able to care for others, and children's efforts to care imaginally responded to such stakes, envisioning futures different from those scripted for them by global health discourses and the conditions of marginalization and exclusion into which they were born. [care; imagination; children; family; global health; Zambia]

\section{MUKUSUPAWILA}

Ukulingana no mulimo wakufwailikisha muncende ishaba mu Lusaka, mu Zambia, uyu mulandu uleleta palwalala ilangulushi lya kusakamana kwa kwelenganya mu kweesha ukusanga umusango umo uwa kusakamana uwasumbulwa ukucila mu cipimo, kabili uwabulamo ifishinka. Mu kupanga ili langulushi, nasenda ulubali lwa baice (abamyaka cine-konse konse ukushinta pamyaka ikumi limo na ibili) abo abaikele mu ndupwa umwali abantu abalecushiwa na malwele ya icifuba ca ntanda bwanga (TB) na kashishi ka bulwele bwa kondoloka (HIV). Abana balibulilemo ulubali mu kusakamana abalwele cila bushiku mu nshila isha pusana pusana. Abana bali abashupikwa mukwesha kwabo ukwa kupeela no kulanga ukusakamana pa mulandu wa mikalile yabo, ishuko lyabo ilya kusanga ifyakubomfya, ukubikapo fye ne mibili yabo iinono. Ukupitila mu filangisho ifingi, ndelangisha inshila isho abana abanono balepanga elyo no kubomfya ifimpasho ifimoneka ifya kusakamana abalupwa mu nshita iyapita, ino, elyo ne ya kuntanshi. Ndelangisha ukutila ukwelenganya ne fimpasho ifyapulamo ifya kuibimbamo kwa bana takwalanga fye ukuti balesakamana abantu bambi (abalwele/abalupwa), lelo kwabombele nge nshila shabo isha kupeelelamo nangu ukubomba umulimo wa kusakamana. Kwali amaafya ayengi elyo ayakulu mubwikashi bwa bana abaleesha ukusakamana bambi. Kabili amaka ya bana mu kusakamana kwa kwelenganya, yalyafwilishe kuli ayo amaafya, ukwelenganya ubupusano bwa kuntanshi ukufuma kuli ifyo ifyalembwa pali bena mu malyashi yabumi aye sonde lyonse elyo ne mibeele ya kusuulwa no kupatululwa, iyo bafyelwemo. [ubusunge; ukwelenganya; abana; ulupwa; ubumi busuma mpanga yonse; Muchalo chesu cha Zambia] 


\section{MWACIDULE}

Kulinganiza ndi nchito yofufuza-fufuza mu madera ya Muzinda wa Lusaka, mu dzoko la Zambia, iyi mbiri ibweretsa ganizo lachisamaliro chofanizira moyetsa kupeza maonekedwe yachisamaliro chakuya, chozama koma chimene chiribe Mfundo zeni-zeni. Pomanga iri ganizo, ndatenga choonerako cha ana ang'ono-ang'ono (ali ndi zaka zisanu ndi zitatu mpaka khumi ndi ziwiri) amene anakhala mu mabanja anali ndi anthu wodwala chifuwa chabefu (TB) ndi matende ya Kaliwondewonde (HIV). Ana anali kutenga mbali yasamara wodwala tsiku ndi tsiku munjira zo siyana-siyana. Anali wobvutika mukugwapo kwawo kopereka ndi kuonetsa chisamaliro chifukwa cha mukalidwe wawo, kukwanisira kupeza zofunikira ndipo kuchepepa kwamathupi yawo. Kupyorera mu zisanzo zambiri, ndiri kuonetsa njira zimene ana anapanga ndi kusewenzetsa kawiri kawiri zifaniziro zoonetsa kupatsa chisamaliro ku anthu mubanja kudala, tsopano ndipo kutsogoro. Ndiri kuonetsa kuti kuyerekeza ndi zifanizo zozama zakugwapo kwa ana pa nchito yachisamariro sizinali kuonetsa kusamalira kwawo ku anthu ena koma kumaonetsa njira zawo zopatsa ndi kusamalira. Kunali mabvuto yayakulu ku ana pa kusagwapo kwawo mu kusamalira anthu ena, ndipo kugwapo kwawo kogwapo kofanizira kunagwebana ndi mabvuto ayo pamene anali kuganizira tsogoro losiyanako ndi zolembedwa mu nkhani yaumoyo yadziko lonse lapansi ndi mukhalidwe wachisankulo ndi kusayesedwa ngati anthu zimene anabadwiramo. [kusamalira; kuganizila; bana; banja; Umoyo Waziko; Dziko la Zambia]

\section{NOTES}

Acknowledgments This article has taken me a long time to write, and I now have many people to thank. Above all, my gratitude goes to the children and their family members who participated in the study, and to Emily Banda and Olivious Moono, the best research assistants I could imagine for this project. I carried out the research on which this article is based with funding from several sources: the National Science Foundation, the Wenner-Gren Foundation, the Fulbright Institute of International Education, and the Association of American University Women. I wrote the article with funding from the Foundation for Barnes Jewish Hospital. Karen Tranberg Hansen and Helen Schwartzman helped nurture the ideas I present in this article long before I knew I would write about them. I benefited greatly from discussing the manuscript in its early stages in Washington University's Ethnographic Theory Workshop, on panels on children's creativity at two conferences (the 2017 Anthropology of Children and Youth Interest Group conference and the 2017 annual meeting of the American Anthropological Association), and with the students in Casey Golomski's class on "Gender, Sexuality, and HIV/AIDS in Sub-Saharan Africa" at the University of New Hampshire. I need to specifically thank Cindy Dell Clark, Helen Schwartzman, Rebecca Lester, Aviva Sinervo, EA Quinn, Kedron Thomas, Brad Stoner, and Emily Steinmetz for providing helpful comments on different versions of the manuscript. Dawn Pankonien deserves special mention for reading drafts, listening and responding to my WhatsApp brainstorms, and pushing me continuously to clarify my thinking. I deeply appreciate the work of the anonymous reviewers and the editors at $\mathrm{Cul}$ tural Anthropology, Christopher Nelson, Heather Paxson, and Brad Weiss. The article is much stronger because of their critical comments and guidance, and because of Heather Paxson's editorial work during the final stages of revision. Finally, I need to acknowledge everyone involved in translating the abstract from English to Bemba and Nyanja, most notably Jebros Fumbelo, and also Lackson Kaunda, Simon Kabanda, Mutale Chileshe, and Chishimba Lumbwe. Natotela sana. Zikomo kwambiri. 
1. Gift Munkanta is a pseudonym, as are all names used in this article,

2. This gallery can be accessed at https://www.flickr.com/photos/childrenascaregivers/ albums.

3. Prompts included: family; everything you did yesterday; who takes care of you and what they do; people in your house, doing what they usually do; map of places you go; yourself caring for a sick person; holiday; school. Children made many self-initiated, unprompted drawings during and between my visits. For more on issues of agency and representation in participatory drawing methods, see Mitchell 2008, Hunleth 2011, and Johnson, Pfister, and Vindrola-Padros 2013.

4. I thank an anonymous reviewer for help in formulating this point.

5. This is likewise my effort to move beyond the problematic notion that participatory methods "give voice" to children.

6. I thank an anonymous reviewer for identifying this point.

7. Note that I never asked children to draw, role-play, or tell stories about taking care of specific persons.

8. I appreciate an anonymous reviewer's observation that the language I use to describe children's imaginal caring holds parallels to language around witchcraft. While children would not describe their caring in terms of witchcraft, their work in other realms bears some similarities to Sonia Silva's (2017) description of asking, giving, and receiving as it relates to witchcraft in Northwestern Province, Zambia. Perhaps caring in other realms held potential to reinclude children in and address their exclusion from reciprocal and intergenerational caring relationships.

9. See extensive studies of children's socialization and creativity in peer play by linguistic anthropologists, such as Goodwin 1990, Watson-Gegeo 2001, and Goodwin and Kyratzis 2012.

10. Children produced these drawings in response to a range of prompts including, but not limited to, "draw yourself caring for a sick person." They also made such drawings without any direction from me and between my visits to their households.

11. I thank Mutale Chileshe, who carries out research with bedsiders on the Zambian Copperbelt, for help with these points.

12. Paul conveyed this message on my recorder in private while describing a sketch that depicted a boy, whom Paul interpreted as a schoolboy. See Hunleth 2017 on this "talking with pictures" method.

13. This sentence plays on Schwartzman's (1979) closing sentence of Transformations, in which she invites anthropologists to see all ethnography as a form of play.

\section{REFERENCES}

Adams, Vincanne, Michelle Murphy, and Adele E. Clarke

2009 "Anticipation: Technoscience, Life, Affect, Temporality." Subjectivity 28, no. 1: 246-65. https://doi.org/10.1057/sub.2009.18.

Aldridge, Jo

2008 "All Work and No Play? Understanding the Needs of Children with Caring Responsibilities." Children and Society 22, no. 4: 253-64. https://doi.org/10.1111/

Allerton, Catherine j.1099-0860.2007.00094.x.

2016 "Introduction: Encountering Children." In Children: Ethnographic Encounters, edited by Catherine Allerton, 1-15. New York: Bloomsbury.

Beidelman, T. O.

1993 Moral Imagination in Kaguru Modes of Thought. Washington, DC: Smithsonian Institution Press. Originally published in 1986.

Biehl, João

2007 Will to Live: AIDS Therapies and the Politics of Survival. Princeton, N.J.: Princeton University Press. 
Bluebond-Langner, Myra

1978 The Private World of Dying Children. Princeton, N.J.: Princeton University Press.

Bluebond-Langner, Myra, and Jill E. Korbin

2007 "Challenges and Opportunities in the Anthropology of Childhoods: An Introduction to "Children, Childhoods, and Childhood Studies." American

Brada, Betsey Behr Anthropologist 109, no. 2: 241-46. https://doi.org/10.1525/aa.2007.109.2.241.

2013 "How to Do Things to Children with Words: Language, Ritual, and Apocalypse in Pediatric HIV Treatment in Botswana." American Ethnologist 40, no. 3: 437-51. https://doi.org/10.1111/amet.12031.

2019 "Between Discipline and Empowerment: Temporal Ambivalence at a Sleepaway Camp for HIV-Positive Children in Botswana." Anthropological Quarterly 92, no. 1: 173-202. https://doi.org/10.1353/anq.2019.0006.

Buchbinder, Mara $\mathrm{H}$.

2008 “'You're still sick!': Framing, Footing, and Participation in Children's Medical Play." Discourse Studies 10, no. 2: 139-59. https://doi.org/10.1177/1461445607087018.

Chua, Jocelyn Lim

2011 "Making Time for the Children: Self-Temporalization and the Cultivation of the Antisuicidal Subject in South India." Cultural Anthropology 26, no. 1: 112-37. https://doi.org/10.1111/j.1548-1360.2010.01082.x.

Clark, Cindy Dell

2003 In Sickness and in Play: Children Coping with Chronic Illness. Piscataway, N.J.: Rutgers University Press.

2016 “Imaginal Coping: Resilience through a Play of Tropes.” In Child and Adolescent Resilience within Medical Contexts: Integrating Research and Practice, edited by Carey DeMichelis and Michel Ferrari, 175-92. Basel, Switzerland: Springer International Publishing.

Colson, Elizabeth

1958 Marriage and the Family among the Plateau Tonga of Northern Rhodesia. Manchester, UK: Manchester University Press.

Comaroff, Jean, and John Comaroff

2002 "Alien-Nation: Zombies, Immigrants, and Millennial Capitalism." South Atlantic Quarterly 101, no. 4: 779-805. https://doi.org/10.1215/00382876-101-4-779.

DeVault, Marjorie L.

1991 Feeding the Family: The Social Organization of Caring as Gendered Work. Chicago: University of Chicago Press.

Foucault, Michel

1993 "Dream, Imagination, and Existence: An Introduction to Ludwig Binswanger's 'Dream and Existence."' In Dream and Existence, edited by Keith Hoeller, 29-78. Atlantic Highlands, N.J.: Humanities Press International. Originally published in 1954.

Garcia, Angela

2016 "The Blue Years: An Ethnography of a Prison Archive." Cultural Anthropology 31, no. 4: 571-94. https://doi.org/10.14506/ca31.4.06.

Goodwin, Marjorie Harness

1990 He-Said-She-Said: Talk as Social Organization among Black Children. Bloomington: Indiana University Press.

Goodwin, Marjorie Harness, and Amy Kyratzis

2012 "Peer Language Socialization." In The Handbook of Language Socialization, edited by Alessandro Duranti, Elinor Ochs, and Bambi B. Schieffelin, 365-90. Malden, Mass.: Wiley-Blackwell.

Hansen, Karen Tranberg

1990 "Labor Migration and Urban Child Labor During the Colonial Period in Zambia." In Demography from Scanty Evidence: Central Africa in the Colonial Era, edited by Bruce Fetter, 219-34. Boulder, Colo.: Lynne Rienner. 
Henderson, Patricia

2006 "South African AIDS Orphans: Examining Assumptions around Vulnerability from the Perspective of Rural Children and Youth." Childhood 13, no. 3: 303-327.

Hunleth, Jean https://doi.org/10.1177/0907568206066354.

2011 "Beyond On or With: Questioning Power Dynamics and Knowledge Production in 'Child-Oriented' Research Methodology." Childhood 18, no. 1: 81-93. https:// doi.org/10.1177/0907568210371234.

2013a “'ARVs' as Sickness and Medicine: Examining Children's Knowledge and Experience in the HIV Era in Urban Zambia." AIDS Care 25, no. 6: 763-66. https://doi.org/10.1080/09540121.2012.748878.

2013b “Children's Roles in Tuberculosis Treatment Regimes: Constructing Childhood and Kinship in Urban Zambia.” Medical Anthropology Quarterly 27, no. 2: 29-311. https://doi.org/10.1111/maq.12028.

2017 Children as Caregivers: The Global Fight against Tuberculosis and HIV in Zambia. New Brunswick, N.J.: Rutgers University Press.

Hunleth, Jean, Rebekah Jacob, Steven Cole, Virginia Bond, and Aimee James

2015 "School Holidays: Examining Childhood, Gender Norms, and Kinship in Children's Shorter-Term Residential Mobility in Urban Zambia.” Children's Geographies 13, no. 5: 501-517. https://doi.org/10.1080/14733285.2014.893280.

Janzen, John M., with William Arkinstall

1978 The Quest for Therapy in Lower Zaire. Berkeley: University of California Press.

Johnson, Ginger A., Anne E. Pfister, and Cecilia Vindrola-Padros

2013 "Drawings, Photos, and Performances: Using Visual Methods with Children." Visual Anthropology Review 28, no. 2: 164-78. https://doi.org/10.1111/j.15487458.2012.01122.x.

Klaits, Frederick

2010 Death in a Church of Life: Moral Passion During Botswana's Time of AIDS. Berkeley: University of California Press.

2017 “Asking in Time.” In The Request and the Gift in Religious and Humanitarian Endeavors, edited by Frederick Klaits, 1-24. New York: Palgrave Macmillan.

Livingston, Julie

2005 Debility and the Moral Imagination in Botswana. Bloomington: Indiana University Press.

Mattingly, Cheryl

2006 "Pocahontas Goes to the Clinic: Popular Culture as Lingua Franca in a Cultural Borderland.” American Anthropologist 108, no. 3: 494-501. https://doi.org/10.1525/ aa.2006.108.3.494.

Mitchell, Lisa M.

2008 "Child-Centered? Thinking Critically About Children's Drawings as a Visual Research Method." Visual Anthropology Review 22, no. 1: 60-73. https://doi.

Ross, Fiona C. org/10.1525/var.2006.22.1.60.

2010 Raw Life, New Hope: Decency, Housing, and Everyday Life in a Post-Apartheid Community. Cape Town: UCT Press.

Schwartzman, Helen B.

1979 Transformations: The Anthropology of Children's Play. New York: Plenum.

Shipton, Parker

2007 The Nature of Entrustment: Intimacy, Exchange, and the Sacred in Africa. New Haven, Conn.: Yale University Press.

Silva, Sonia

2017 "Witchcraft and the Gift: Killing and Healing in Northwest Zambia." In The Request and the Gift in Religious and Humanitarian Endeavors, edited by Frederick Klaits, 25-45. New York: Palgrave Macmillan. 
Stevenson, Lisa

2014 Life Beside Itself: Imagining Care in the Canadian Arctic. Oakland: University of Taussig, Michael California Press.

2009 “What Do Drawings Want?" Culture, Theory, and Critique 50, nos. 2-3: 263-74. https://doi.org/10.1080/14735780903240299.

von Benzon, Nadia

2015 “I fell out of a tree and broke my neck': Acknowledging Fantasy in Children's Research Contributions." Children's Geographies 13, no. 3: 330-342. https://doi. org/10.1080/14733285.2013.829662.

Vygotsky, Lev S.

1967 "Play and Its Role in the Mental Development of the Child." Soviet Psychology 5, no. 3: 6-18. https://doi.org/10.2753/RPO1061-040505036.

Watson-Gegeo, Karen Ann

2001 "Fantasy and Reality: The Dialectic of Work and Play in Kwara'ae Children's Lives.” Ethos 29, no. 2: 138-58. https://doi.org/10.1525/eth.2001.29.2.138.

Weiss, Brad

2002 "Thug Realism: Inhabiting Fantasy in Urban Tanzania." Cultural Anthropology 17, no. 1: 93-124. https://doi.org/10.1525/can.2002.17.1.93.

White, Luise

2000 Speaking with Vampires: Rumor and History in Colonial Africa. Berkeley: University of California Press.

Whyte, Susan Reynolds, ed.

2014 Second Chances: Surviving AIDS in Uganda. Durham, N.C.: Duke University Press. Winnicott, D. W.

2005 Playing and Reality. New York: Routledge. Originally published in 1971. 